\title{
Characteristics and Readiness of Oil Palm Households for Replanting Program: Is an Empowerment Program Needed?
}

\author{
Ardi Novra \\ CoE Sustainable Integrated Farming System (SIFAS), Faculty of Animal Science, \\ Jambi University, Jambi, Indonesia. ardinovra@unja.ac.id \\ Adriani Yogaswara \\ CoE Sustainable Integrated Farming System (SIFAS), Faculty of Animal Science, \\ Jambi University, Jambi, Indonesia. adrianiyogaswara@unja.ac.id \\ Fatati Abubakar \\ CoE Sustainable Integrated Farming System (SIFAS), Faculty of Animal Science, \\ Jambi University, Jambi, Indonesia. abubakarfatati@yahoo.co.id \\ Corresponding Author: Ardi Novra: ardinovra@unja.ac.id
}

\begin{abstract}
This article describes a new idea of how the level of intervention in household empowerment policies is based on an empirical study of the magnitude of the negative impact of the smallholder palm oil replanting (SPR) program. One of the negative impacts of this program is the temporary loss of income (TLI) for farmer households due to the cessation of production of oil palm fruit bunches. The household survey research was conducted in three village centers for smallholder oil palm plantations in Jambi Province, Indonesia. The research result shows that the average potential TLI in each household if replanting palm oil is carried out is IDR $2,364,644 /$ month (equivalent to $74.55 \%$ of the oil palm household income or $39.78 \%$ of the regional economy), Purwodadi Village is the village most vulnerable to regional economic disturbances due to the high potential for TLI, reaching $99.43 \%$ of the oil palm household income and $67.06 \%$ of the regional economy. The level of TLI is influenced by factors of age and area of old oil palm plants, the proportion of households that will undergo the replanting process, and the level of dependence of regions on oil palm. Based on the results of the research, it can be concluded that there is still a need for innovation and expansion of empowerment to encourage household readiness in facing the SPR program.
\end{abstract}

Keywords. empowerment, households, loss income, oil palm, replanting

\section{Introduction}

Oil palm is a blessing given by God Almighty with a long journey from Africa to Indonesia until it is finally widespread in Sumatra and Kalimantan. At first, the presence of oil palm plants was only a legacy of the Dutch Colonial Government which slowly became a commercial crop [1\}. In the early 1980 s, the development of oil palm plants began to propagate until it reached an area of 200,000 ha and up to now the area of oil palm plantations has reached 18.03 million ha. Oil palm plantations have developed in 190 districts as indicated by the oil palm plantation multiplier index which is larger than the sector average [2]. Indonesia has succeeded in becoming the world's largest producer of palm oil and this commodity has become a mainstay of state revenue from taxes and export revenues. Palm oil products and their derivatives are in the first place for the largest contribution to non-oil and gas exports and have an important impact on the structure of the trade balance. The grouping of oil palm plants into 4 age groups, namely young plants (3 - 8 years), adolescents ( 9 - 13 years), adults (14 - 20 
years), and old ( $>20$ years) are related, among others, to oil yield, production, comparison. male and female flowers [3].

The Smallholder Palm Oil Replanting Program (SPR) is an effort to develop plantations by replacing old /unproductive plants with new plants, either in whole or in stages [4]. The SPR program will become the new foundation for smallholder oil palm plantations in Indonesia because it is not only replanting old trees but also fixing many things [5]. Through the SPR, many things can be addressed from plantations. smallholder palm oil which has been proven to be the support of the regional economy [6]. The main actor of the SPR is the household, so their participation is a key factor and the results of the research show that economic factors are one of the causes for the low participation rate of replanting [7]. Furthermore, there is a significant relationship between the factors of knowledge, access to information, extension activities, capital, income, and farming experience on oil palm replanting [8].

Since 2017, the government, through the Ministry of Agriculture's Directorate General of Plantation and the Indonesian Ministry of Finance's Palm Oil Plantation Fund Management Agency, has started the Smallholders Palm Oil Replanting (SPR) Program. The program that was launched directly by President Jokowi in Banyuasin (South Sumatra) was intended to increase the productivity of people's palm oil, which is still low. According to data from the Ministry of Agriculture, the realization of oil palm rejuvenation in 2017-2018 has only reached 4,223 hectares, which is still far from the technical recommendations for oil palm rejuvenation as a condition for obtaining funding from the Plantation Fund Management Agency (PFMA) of 14,792 hectares, as well as last year's SPR program target of 20,780 hectares [4]. The Indonesian Palm Oil Farmers Association hopes that increased productivity through the SPR program can be supported by easy procedures for farmers and asks that one or two conditions be made easier [9]. To accelerate the realization of the SPR program, the Government has again relaxed the procedures or requirements from the current eight (previously 14) to be simplified again to only two requirements [10]. The government is targeting the PSR program to target 500 thousand hectares (ha) of smallholder oil palm plantations in the next three years (2020-2022) and expected that the productivity of smallholder oil palm plantations will increase significantly.

One of the obstacles felt in the rejuvenation program is the technical problems of the bureaucracy which are regulated in the Decree of the Director-General of Plantation No. 29/ KPTS / KB.120/3/2017 [4]. The question arises "is it just a bureaucratic technical obstacle?" because in reality there are economic uncertainties that will be faced during the replanting period. Is it true that a structured empowerment program is not needed to develop alternative sources of income to increase household economic readiness in facing the SPR program?. The replanting program, among others, has an impact on the existence of non-productive periods of plants that cause plantations to be cut off, factory continuity is not maintained due to reduced supply of FFB, and even opportunities for the plundering of land are quite vulnerable [11]. The temporary loss of income is one of the consequences of the SPR program due to production cessation so that the palm oil household's income will be lost until the replanting plants can produce an estimated 3-4 years [12]. So far, the non-productive period or the interruption of plantation income has not been the focus of attention of many parties even though it has had a broad impact on the success and sustainability of the SPR program.

Agricultural households need income not only for consumption needs but also as capital to finance the maintenance of replanting oil palm trees. The use of income to fulfill consumption needs becomes a priority and if it is met, it will be used for savings and capital. The majority of oil palm farmers are monocultures so that when the production of fresh fruit bunches stops and this implies the loss of a large proportion of household income. Limited capital due to low or loss of the main source of income will reduce the intensity of plant maintenance such as fertilization and pest control. The impact of this condition will cause the main objective of the SPR program to increase the productivity of oil palm plants is not achieved. The SPR program's target for the welfare of farmers will lead to a higher poverty rate. For this reason, anticipatory and responsive action from policymakers is needed to empower affected households. The effectiveness and intensity of a policy will be closely related to the ability to understand field conditions and one of them is the magnitude of the impact on the target community for the policy. 
Based on the description above, a study was carried out on the level of household readiness of oil palm farmers in facing the SPR program and an empowerment model that could be carried out to increase their readiness to face temporary income loss until the replanting oil palm yields an economic level of production.

\section{Literature Review}

A household is defined by the U.S. Census Bureau as all the people who occupy a single housing unit, regardless of their relationship to one another [13]. The household, rather than the individual, is commonly adopted as the basic unit of analysis when considering the economic situation of society (though data for individuals may be collected separately). The household is recommended by the Canberra Group of experts for use in studying income distributions and is the basic unit in household budget surveys, the main purpose of which is to assist in the creation of retail price indices (cost-ofliving indices). In an agricultural context, it is adopted by the FAO as the foundation for its System of Economic Accounts for Food and Agriculture (SEAFA), intended for use by countries at all levels of economic development [14]. Within the EU, Eurostat measures the total income of agricultural households. In the United States, incomes for farm occupier households are calculated by the United States Department of Agriculture's Agriculture Resources Management Survey (ARMS) (the forerunner of which was the Farm Costs and Returns Survey).

For the System, a household may be defined as a small group of persons who share the same living accommodation, who pool some, or all, of their income and wealth, and who consume certain types of goods and services collectively, mainly housing and food [15]. A central feature of the household is that there is a high degree of pooling of income and expenditure. This means that assessment at the level of the household is more meaningful in representing the potential command over goods and services than would be the case if the incomes of the individual members were treated separately. This is not to deny that, for example, farmer's wives may have some source of income which they regard as their own (such as from providing bed-and-breakfast accommodation in the farmhouse), or that the pocket money which a farmer spends is the result of a collective decision and is approved as a necessary line of expenditure by the household. In many countries spouses work off the farm operation at a wide variety of occupations. When asked, they commonly report that their earnings go to increase the overall household income.

In developing countries, the concept of the household can be rather different from that applicable among OECD Members. This is reflected in the UN in its guidelines for population and housing censuses, taken over into the draft methodological recommendations for the World Programme of Agricultural Censuses scheduled for 2010. These describe a household as follows: "The concept of household is based on the arrangements made by persons, individually or in groups, for providing themselves with food or other essentials for living. A household may be either (a) a one-person household, that is to say, a person who makes provision for his or her food or other essentials for living without combining with any other person to form part of a multi-person household, or (b) a multi-person household, that is to say, a group of two or more persons living together who make common provision for food or other essentials for living [12]. The persons in the group may pool their incomes and may, to a greater or lesser extent, have a common budget; they may be related or unrelated persons or constitute a combination of persons both related and unrelated [16].

Household income is any money or cash flow that comes into the home consistently, either through work or investments [17]. Household income is the combined gross income of all members of a household who are 15 years or older, and a single person occupying a dwelling by himself is also considered a household [18]. Individuals do not have to be related in any way to be considered members of the same household. The most common procedure when selecting which variable to use is to turn to those variables that represent an individual's income or expenditure. Both income and expenditure demonstrate advantages and disadvantages in measuring poverty [19]. Gross National Product (GNP) and household incomes are initially calculated in national currencies and then converted by purchasing power parities (PPPs) which take account of different price levels between [20]. In many countries, household income statistics based on sample data, and to assess the accuracy of the result, estimates to aggregate income are often compared the external sources [21]. 
A household is considered to be an agricultural household when at least one member of the household is operating a holding (farming household) or when the household head, reference person, or main income earner is economically active in agriculture [22]. There are three main sources of household income: earned income, investment income, and government assistance [17]. In developing countries, where farming plays a crucial role in the economy, the nonfarm economy plays a significant role in the household agricultural income system based on the returns (farm returns vs. nonfarm returns). Farms refer to the sum of crops, livestock, and other farm-related goods and services [23]. Smallholder farming is the primary source of income and employment in rural, but households tend to diversify their sources because of the need to manage risks, secure a smooth flow of income, allocate surplus labor, respond to various kinds of market failures, and apply coping strategies [24]. Rural households' source of revenue changes daily, and many studies have suggested that nonfarm income is the main source of income in rural areas [2], but no evidence that African households are on a different trajectory than households in other regions in terms of transitioning to non-agricultural based income strategies [24].

Income originating from old oil palm plantations (prospective replanting) is assumed to be a loss of income if oil palm replanting is carried out at the time of data collection. The grouping of oil palm plants into 4 age groups, namely young plants ( $3-8$ years), adolescents ( $9-13$ years), adults (14 - 20 years), and old ( $>20$ years) are related, among others, to oil yield, production, comparison. male and female flowers [2]. Oil palm plants with native seeds reach a maximum production rate $(>30$ tonnes/ha/year) at the planting age of 7-12 years, and after that, they begin to decline until they reach a production level of $<20$ tonnes/ ha/year at the planting age of 20 years. The conditions are different from smallholder oil palm plantations which partly use fake seeds where the maximum production is only \pm 15 tonnes/ha/year and at the planting age of 20 years, it is only able to produce below 10 tonnes/ha/year. The productivity of oil palm plantations will increase after reaching the age of 9 years, then until the age of 13 years, it will stabilize, and begin to decline after the age of 14 until the nonproductive period. (25 years). This pattern of productivity movement is not directly followed by the income pattern of oil palm households because of the price factor [24].

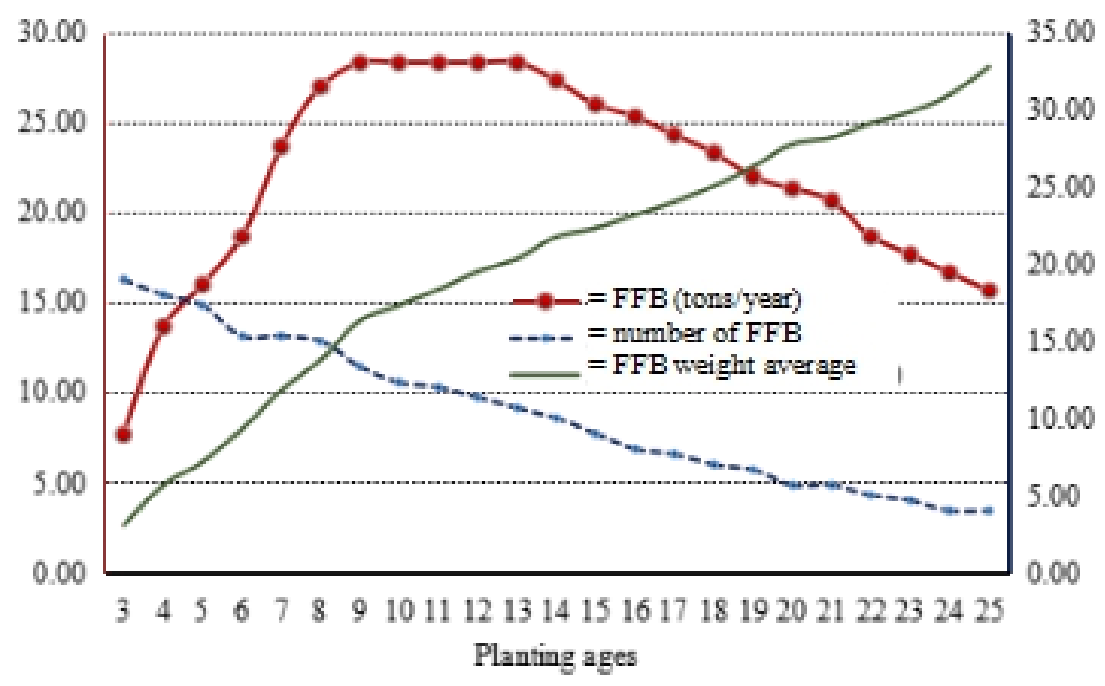

Figure 1. Relationship between age and productivity of oil palm plants

The loss of income even though it is temporary is one of the consequences of the replanting program due to cessation of production so that the household income of oil palm farmers will be lost until the replanting plants can produce again, which is estimated to be $3-4$ years [25]. 


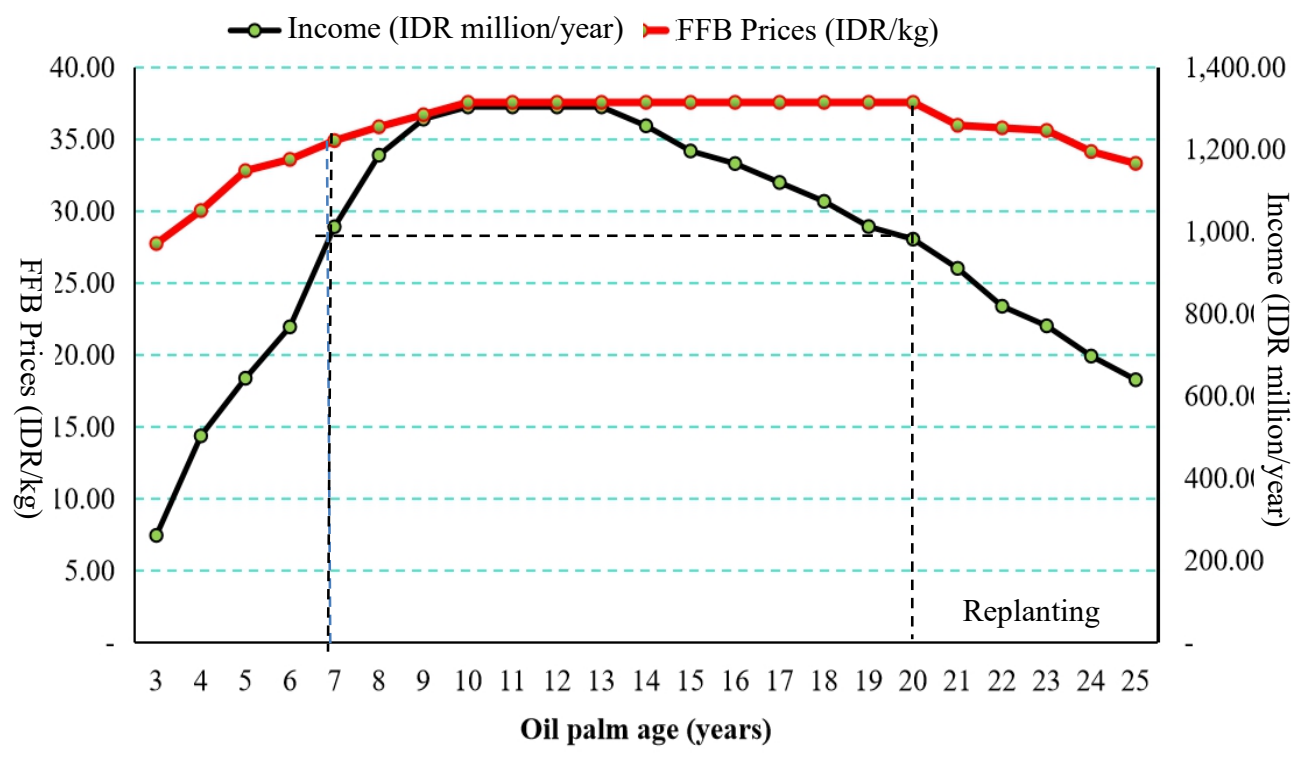

Figure 2. Relationship between Age, Productivity, Price and Household Income

Furthermore, to determine the criteria for the magnitude or level of impact and the level of need for the community empowerment program, the following indicators are used: It is estimated that the higher the level of relationship between households and oil palm farming, the greater the potential for temporary loss of income. The accumulation of the magnitude of the temporary income loss rate and the proportion of oil palm households in an area will have an impact on the regional economy and will require the required intensity of empowerment programs.

\section{Materi and Methods}

Research using a survey method was carried out for 6 (six) months with the analysis unit was 152 households in 3 central oil palm plantation villages in Tanjung Jabung Barat Regency, Jambi. The selection of the three central villages, namely Purwodaadi (PW), Dataran Kempas (DK), and Sungai Keruh (SK) in Tebing Tinggi District was carried out by using purposive sampling technique, namely the village centers for smallholder oil palm plantations which were the targets of the Desa Makmur Peduli Api (Prosperous Village Cares about Fire) program of Industrial Plantation Forest (IPF) companies. PT. Wira Karya Sakti initiated by Sinar Mas Pulp and Paper. The data analysis method is carried out in stages with a simple mathematical approach as in Table 1 below;

Table 1. Steps in estimating the loss of household income and the economic impact of the people's palm oil replanting program

\begin{tabular}{|c|c|c|c|}
\hline No & Variable & Symbol & Formulation \\
\hline 1 & Number of households & RH & \\
\hline 2 & Households average income & AI & \\
\hline 3 & The region income & RTI & $=\mathrm{RH} \times \mathrm{AI}$ \\
\hline 4 & The number of agr. households & $\mathrm{AH}$ & \\
\hline 5 & Average of agr. household income & AHI & \\
\hline 6 & Agricultural income (IDR) & TAG & $=\mathrm{AH} \times \mathrm{AHI}$ \\
\hline \multirow[t]{3}{*}{7} & Share of agriculture sector & & \\
\hline & a. Number of households (\%) & $\mathrm{AGH}$ & $=(\mathrm{AH} / \mathrm{H}) \times 100 \%$ \\
\hline & b. Income $(\%)$ & AGI & $=(\mathrm{AHI} / \mathrm{AI}) \times 100 \%$ \\
\hline 8 & Number of oil palm households & $\mathrm{OPH}$ & \\
\hline 9 & Oil palm household income & OPI & \\
\hline \multirow[t]{3}{*}{10} & Share of oil palm commodity & & \\
\hline & a. Magnitude or value (IDR) & $\mathrm{OPC}$ & $=\mathrm{OPH} \times \mathrm{OPI}$ \\
\hline & b. Share to agricultural sector $(\%)$ & OPA & $=(\mathrm{OPC} / \mathrm{TAG}) \times 100 \%$ \\
\hline
\end{tabular}


c. Share to regional economic (\%)

11 Loss income estimation

a. Number of oil palm replanting

b. Total land area to replanting (Ha)

c. Old palm productivity (ton/Ha)

d. FF Price (IDR/kg)

e. Old oil palm income (IDR)

12 Households affected (\%)

a. Oil palm households

b. Agricultural households

c. Regional households

13 Relatively Household Loss Income

14 The economic impact of TLI on the

a. Agricultural sector (\%)

b. Region (\%)
OPR

$=(\mathrm{OPC} / \mathrm{RTI}) \times 100 \%$

RPH

OLA

OPP

PFP

TLI

$=$ OLA $\times$ OPP $\times$ PFP

HOP $=(\mathrm{RPH} / \mathrm{OPH}) \times 100 \%$

HAG $=(\mathrm{RPH} / \mathrm{AH}) \times 100 \%$

HRG $\quad=(\mathrm{RPH} / \mathrm{RG}) \times 100 \%$

HLI $=(\mathrm{TLI} / \mathrm{OPJ}) \times 100 \%$

EIAS

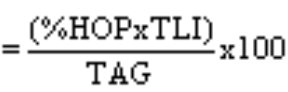

EIRG

Sources: Novra (2019)

Furthermore, to determine the criteria for the magnitude or level of impact and the level of need for the community empowerment program, the following indicators are used (Table 2)

Table 2. Indicators of need level assessment of household empowerment programs

\begin{tabular}{clcl}
\hline No & The magnitude of the impact & Criteria & $\begin{array}{l}\text { The need for an empowerment } \\
\text { program }\end{array}$ \\
\hline 1 & $<20 \%$ & Very low & Don't need empowerment \\
2 & $20.00-40.00 \%$ & Low & Need limited empowerment \\
3 & $40.00-61.00 \%$ & Enough & Need programmed empowerment \\
4 & $60.00-80.00 \%$ & High & Empowerment is urgently needed \\
5 & $80.00-100 \%$ & Very high & Empowerment must be done \\
\hline
\end{tabular}

\section{Result and Discussion}

\subsection{Socioeconomic and culture of the village of oil palm}

The ability of local policy to influence distributional patterns is implied to the extent that local action can facilitate variable growth rates of targeted economic sectors [27]. .A critical aspect of rural research is carefully defining and describing the rural context, because different definitions of rural may influence resource allocation, grant funding eligibility, and/or research findings [28]. The socioeconomic characteristics of the three smallholder oil palm plantation center areas have quite varied differences from the results of interviews with household information sources as presented in Table 3 .

Table 3. Personal characteristics of selected respondents in each study area village

\begin{tabular}{lrrr}
\hline \multirow{2}{*}{ No Characteristics of sources information } & \multicolumn{3}{c}{ Proportion (\%) } \\
\cline { 2 - 4 } & SK & DK & PW \\
\hline 1 Age (years) & 44.02 & 40.27 & 43.96 \\
2 Gender & & & \\
a. Man & 84.31 & 82.35 & 86.00 \\
b. Women & 15.69 & 17.65 & 16.00 \\
3 & & & \\
Education & 7.84 & 3.92 & 6.00 \\
a. Not school & 9.80 & 1.96 & 10.00 \\
b. Not completed elementary & 19.61 & 27.45 & 36.00 \\
c. Elemnetary school & 17.65 & 21.57 & 28.00 \\
d. Junior hight school & & &
\end{tabular}




\begin{tabular}{lrrr} 
e. Senior hight school & 43.14 & 33.33 & 20.00 \\
f. University of Diploma & 1.96 & 11.76 & - \\
\hline Jumlah & 100.00 & 100.00 & 100.00 \\
\hline
\end{tabular}

Sources: Primary data processing, 2020

The majority of sources of information are the population of productive age with the opposite sex of men and with middle-level education (junior and senior high school). Specifically for PW Village, the proportion of information sources with primary school education level is the highest, on the other hand for SK Village the proportion of high school education level is the highest. The proportion of information sources with a higher education level (university and diploma) is relatively low except for DK Village which is quite high, reaching $11.76 \%$. The education structure of this information source will be closely related to their attitudes and information towards various programs that have been and are currently taking place in their village areas including SPR and community empowerment through the DMPA program. Another factor that has the potential to influence people's attitudes and perceptions is the involvement in institutions and the type of work they are engaged in as presented in Tables 4 and 5.

Table 4. The involvement in socio-economic institutions in each research area village (\%)

\begin{tabular}{llrrr}
\hline \multirow{2}{*}{ No } & Institutional Indicators & \multicolumn{3}{c}{ Village } \\
\cline { 2 - 5 } & Institution Participation & DK & PW \\
\hline a. Farmer Group & 24.00 & 58.00 & 34.00 \\
b. Cooperation & 6.00 & 32.00 & 14.00 \\
\hline 2 & Social Status & & & \\
a. General public & 88.24 & 92.16 & 96.00 \\
b. Religion leaders & - & - & - \\
c. Custom figures & - & 1.96 & - \\
d. Youth leaders & 1.96 & - & 2.00 \\
& e. Women characters & - & 5.88 & 2.00 \\
\hline
\end{tabular}

Sources: Primary data processing, 2020

The farmer institution is one of the requirements as a potential recipient or participant of the SPR program in addition to proof of land ownership. Household participation in village economic institutions, both specifically in the field of agriculture (farmer groups) and general (cooperatives), is relatively high although it is still below $50 \%$, especially cooperatives. The comparison between the three villages shows that the household participation rate in DK village is higher than in the other villages. The characterization of certain figures in society tends to be more formal than informal, such as religious and customary figures. This is related to the demographic structure of the population based on origin, the majority of which are migrants, both transmigration and independent migrants (See Table 6). The high level of household participation in farmer groups is related to the source of household income both as a main job and a part-time job as shown in Table 5.

Tabel 5. Types of main and secondary occupations in each research area village

\begin{tabular}{clrrr}
\hline \multirow{2}{*}{ No } & \multirow{2}{*}{ Type of Job } & \multicolumn{3}{c}{ Village } \\
\cline { 2 - 4 } 1 & Main Job & SK & DK \\
& a. On-farm & 35.29 & 39.22 & 38.00 \\
& b. Off-farm & 9.80 & 17.65 & 16.00 \\
& c. Non-farm & 54.90 & 43.14 & 46.00 \\
\hline 2 & Side Job & 19.61 & 41.18 & 16.00 \\
& a. On-farm & 1.96 & 19.61 & 4.00 \\
& b. Off-farm & 5.88 & 15.69 & 8.00
\end{tabular}




\begin{tabular}{|c|c|c|c|c|}
\hline & c. Non-farm & 11.76 & 5.88 & 4.00 \\
\hline & d. Not have & 80.39 & 58.82 & 76.00 \\
\hline \multirow[t]{4}{*}{3} & Total & & & \\
\hline & a. On-farm & 37.25 & 58.82 & 42.00 \\
\hline & b. Off-farm & 15.69 & 33.33 & 24.00 \\
\hline & c. Farmer & 52.94 & 92.16 & 66.00 \\
\hline
\end{tabular}

Sources: Primary data processing, 2020

The composition of the types of work shows that the majority of households in the three villages are agricultural households with the main type of work being landowners, especially in DK Village. Working in the agricultural sector besides being the main job is also a side job, both on-farm and offfarm. It is assumed that the composition of the main and side income sources of the SPR program will not only have an impact on the household economy but also the regional or village economy. This variation in types of work is influenced by socio-demographic variations, which are reflected in the status or origin of the population of each village as presented in Table 6.

Table 6. Population composition is based on the region of origin in each village.

\begin{tabular}{clccc}
\hline \multirow{2}{*}{ No } & \multirow{2}{*}{ Stattus Kependudukan } & \multicolumn{3}{c}{ Name of villages } \\
\cline { 3 - 5 } & & SK & DK & PW \\
\hline \multirow{2}{*}{2} & Native communities & 60.78 & 29.41 & 44.00 \\
& Migrant & 39.22 & 70.59 & 56.00 \\
& a. Transmigration & 9.80 & 31.37 & 34.00 \\
& b. Next generation of trans & 5.88 & 11.76 & 4.00 \\
& c. Non-transmigrant & 23.53 & 27.45 & 18.00 \\
\hline
\end{tabular}

Sources: Primary data processing, 2020

The majority of SK villages are indigenous people, while the other two villages are mostly inhabited by migrants. DK Village is an expansion area of PW Village which was originally a transmigration village. The economy of PW Village, which has been developing, has attracted some migrants and on the other hand, DK Village has become the target of expanding residential and cultivation land, especially the next generation of transmigration families. This causes the proportion of the migrant population of DK village to be higher than that of the main village, namely PW. Indications of the village of DK as a target area for farming expansion by transmigrants and families as well as looking for work can be seen from the destination of migrant arrivals and the ethnic diversity that resides in the village (Table 7).

Table 7. The purpose and ethnicity of the migrant population who live in each village

\begin{tabular}{|c|c|c|c|c|}
\hline \multirow{2}{*}{ No } & \multirow{2}{*}{ Migrant motive and ethnic } & \multicolumn{3}{|c|}{ Name of villages } \\
\hline & & SK & DK & $\mathrm{PW}$ \\
\hline \multirow[t]{7}{*}{1} & Migrant motive & & & \\
\hline & a. Opening land & 14.29 & 17.65 & 11.11 \\
\hline & b. Looking for work & 52.38 & 20.59 & 40.74 \\
\hline & c. Trade or business & 4.76 & 2.94 & 0.00 \\
\hline & d. Follow parents & 14.29 & 47.06 & 25.93 \\
\hline & e. Joint family & 14.29 & 5.88 & 22.22 \\
\hline & f. Assignment & 0.00 & 5.88 & 0.00 \\
\hline \multirow[t]{5}{*}{2} & Migrant Ethnics & & & \\
\hline & a. Jambi Malay & 3.33 & 4.17 & 8.70 \\
\hline & b. Java & 76.67 & 25.00 & 71.74 \\
\hline & c. Sundaes & 6.67 & 56.25 & 8.70 \\
\hline & d. Batak & 6.67 & 10.42 & 4.35 \\
\hline
\end{tabular}


e. Others

6.67

4.17

6.52

Sources: Primary data processing, 2020

The majority of migration motives are for economic purposes, either directly (clearing land, looking for work, and opening a business) or indirectly on the grounds of following family (parents and siblings). The development of welfare and the availability of sufficient land, especially after the increase in the price and productivity of oil palm plants, have become one of the factors that have attracted the entry of migrant populations of various ethnicities. The expansion of the people of PW Village also crosses regional boundaries including in neighboring villages such as SK although they are still an ethnic minority in the village. The two largest ethnic immigrants are Javanese and Sundanese, who spread in groups as indicated by the ethnic structure of immigrants in DK and PW villages. The village of $\mathrm{PW}$ as the main village is more dominated by Javanese ethnicity, while the village of DK as the result of the division is dominated by Sundanese ethnicity. Several other ethnic groups who live in the three villages are Batak (North Sumatra), Padang (West Sumatra), Bugis and Makassar (South Sulawesi). These other ethnicities generally settled in the three villages to open trading businesses and some invested to open plantation land as a side income.

\subsection{Socio-economic characteristics and cultivation pattern}

The widespread traditional image of farm households in developing countries has focused, almost exclusively, on farming with little attention to rural non-farm activities [29]. Policy debate still tends to equate farm incomes with rural incomes and rural/urban relations with farm/non-farm relations [30]. Thus, policymakers view state efforts to combat rural poverty as policies taken to enhance farm productivity. Most official reports produced by governments and multilateral institutions such as the World Bank, as well as others, who have shaped the agricultural policy agenda, have focused almost exclusively on agricultural development as the way to reduce rural poverty and achieve sustainable economic growth in rural areas [31]. Households residing in the three villages are generally small families as indicated by the average number of family members ranging from 3.86 to 4.59 people/family (see Table 8).

Table 8. Household Structure based on Gender and Family Card and Existing Condition in Each Research Village

\begin{tabular}{|c|c|c|c|c|}
\hline \multirow{2}{*}{ No } & \multirow{2}{*}{ Variable } & \multicolumn{3}{|c|}{ Villages } \\
\hline & & SK & DK & PW \\
\hline \multirow[t]{5}{*}{1} & Number of family & & & \\
\hline & a, Man & 2.29 & 1.96 & 2.02 \\
\hline & b. Women & 2.29 & 1.90 & 2.10 \\
\hline & Total & 4.59 & 3.86 & 4.12 \\
\hline & Sex Ratio $(\%)$ & 100.00 & 103.09 & 96.19 \\
\hline \multirow[t]{7}{*}{2} & Main family & 4.57 & 3.55 & 4.00 \\
\hline & a, Man & 2.31 & 1.80 & 2.00 \\
\hline & b. Women & 2.25 & 1.75 & 2.00 \\
\hline & Non-core family & 0.20 & 0.65 & 0.28 \\
\hline & a, Man & 0.16 & 0.41 & 0.24 \\
\hline & b. Women & 0.04 & 0.24 & 0.04 \\
\hline & Total & 4.76 & 4.20 & 4.28 \\
\hline 3 & Non-core family portion & 4.12 & 15.42 & 6.54 \\
\hline 4 & Sex-Ratio (\%) & 107.69 & 111.88 & 109.80 \\
\hline
\end{tabular}

Sources: Primary data processing, 2020

The difference between the average household structure based on the family card and the existing conditions indicates the mobility of the villagers both entering and leaving the village. The larger number of family members based on existing conditions (residents of the house during the survey) indicates the number of new family members, especially for DK Village. If we return to the status of 
residence in the previous section, it can be concluded that the majority of DK Village is Sundanese, many of which include family members and live (hitchhike) in their relatives' homes. This is reinforced by the difference in the sex ratio which is higher than that recorded in the family card. This difference in ratio also indicates that the family members of these migrants are generally male. The residents of these three villages generally live in groups (colonies) so that their farming land is located separately from the center of the settlement as shown in Table 9.

Table 9. Settlement patterns and typical household farming in each research village

\begin{tabular}{|c|c|c|c|c|}
\hline \multirow{2}{*}{ No } & \multirow{2}{*}{ Settlement ad farm type } & \multicolumn{3}{|c|}{ Villages } \\
\hline & & SK & DK & PW \\
\hline \multirow[t]{3}{*}{1} & Resdidental area $\left(\mathrm{m}^{2}\right)$ & 617.39 & 909.90 & 1601.90 \\
\hline & a. Housing & 93.98 & 91.65 & 104.74 \\
\hline & b. The house yard & 523.41 & 818.25 & 1497.16 \\
\hline \multirow[t]{3}{*}{2} & Settlement typical & & & \\
\hline & a. Coloni & 70.59 & 92.16 & 76.00 \\
\hline & b. Individual & 29.41 & 7.84 & 24.00 \\
\hline \multirow[t]{4}{*}{3} & Agricultural land type & & & \\
\hline & a. Blends with the settlement & 13.73 & 19.61 & 48.00 \\
\hline & b. Separated from the settlement & 68.63 & 47.06 & 46.00 \\
\hline & c. Not have agricultural land & 17.65 & 33.33 & 6.00 \\
\hline
\end{tabular}

Sources: Primary data processing, 2020

Community settlements, although in the form of colonies, have a large enough yard so that they are the potential to be used for alternative economic development, including for oil palm farmer households who are entering the replanting period. This is important because it sees the high dependency burden on the three villages and is related to technology adoption (Table 10).

Table 10. Age structure and dependency rate of household

\begin{tabular}{llrrr}
\hline \multirow{2}{*}{ No } & Households Structure & \multicolumn{3}{c}{ Village } \\
\cline { 2 - 4 } & & \multicolumn{1}{c}{ SK } & DK & PW \\
\hline $1 \quad$ Household member & 1.06 & 1.16 & 1.34 \\
a. Children (<15 years) & 0.51 & 0.55 & 0.58 \\
- Man & 0.55 & 0.61 & 0.76 \\
- Women & 3.18 & 2.35 & 2.38 \\
b. Productive (15 - 60 years) & 1.59 & 1.33 & 1.32 \\
- Man & 1.59 & 1.02 & 1.06 \\
- Women & 0.49 & 0.22 & 0.34 \\
c. Old (> 60 years) & 0.29 & 0.12 & 0.16 \\
- Man & 0.20 & 0.10 & 0.18 \\
- Women & & & \\
Households productive ages & 3.18 & 2.35 & 2.38 \\
a. Member number (people) & 67.22 & 63.16 & 58.62 \\
b. Proportion (\%) & & & \\
Dependency Ratio or DR (\%) & 33.33 & 49.17 & 56.30 \\
a. Chid (CDR) & 15.43 & 9.17 & 14.29 \\
b. Old (ODR) & 48.77 & 58.33 & 70.59 \\
Total (DR) & & &
\end{tabular}

Sources: Primary data processing, 2020

Overall, productivity does not seem to fall with age, although it may decrease as time spent in a particular job increases, with routinization leading to falls in motivation, or overuse leading to physical harm [32]. That productivity in this plant which is typical for large-scale manufacturing does not 
decline at least up to age 60 [33]. Productivity reductions at older ages are particularly strong when problem-solving, learning, and speed are important, while older individuals maintain a relatively high productivity level in work tasks where experience and verbal abilities matter more [34]. The consumption and productivity-adjusted dependency ratio are consistently lower than the one that is traditionally defined; the differences between the traditional dependency ratio and the consumptionand productivity-adjusted dependency ratio grow larger in the more distant future, and household composition significantly affects household consumption and medical expenditures [35]. This dependency burden on investment is consistent with a similar study in Ghana who found that households with a high dependency ratio made significantly fewer investments in water management than adopters [36]. The extending strategy can regulate dependency ratio forming households with greater productive capacity, due to larger labor forces, and hence the potential for superior economic performance and family household composition is described as a concomitant of application of extending strategies [37].

\subsection{Palm oil replanting and temporary loss income}

One of the impacts of the oil palm replanting program is the cessation of production which has implications for losing the source of household income for farmers. This loss of income can take place from land clearing until the oil palm trees that are replanted can produce FFB again. The first step in estimating the impact of the PSR program on the regional economy (villages) and smallholder households is to identify patterns of distribution of land ownership for oil palm cultivation and income received as presented in Table 11.

Table 11. The pattern of land ownership and palm oil household farming business income

\begin{tabular}{rlrrr}
\hline \multirow{2}{*}{ No } & Land Owner Pattern & \multicolumn{3}{c}{ Village } \\
\cline { 2 - 5 } & & \multicolumn{1}{r}{ SK } & 52.94 & PW \\
\hline 1 & Land ownver proportion & 31.37 & 66.00 \\
& a. Single ownership & 23.53 & 41.18 & 30.00 \\
& b. Multiple ownership & 7.84 & 11.76 & 36.00 \\
2 & Owned and area (Ha) & & & \\
& a. First field & 2.04 & 1.76 & 2.14 \\
& b. Second field & 0.21 & 0.21 & 0.45 \\
& c. Thirth field & - & - & 0.08 \\
& Total areas (Ha) & 2.25 & 1.97 & 2.67 \\
3 & Age average of palm (years) & 16.50 & 16.94 & 21.09 \\
4 & Monthly Income (IDR) & $2,939,796$ & $3,600,000$ & $2,395,100$ \\
\hline
\end{tabular}

Sources: Primary data processing, 2020

The proportion of households owning land in the three smallholder oil palm center villages varies with the number of garden plots of more than one, especially in PW Village. This indicates that PW Village as a transmigrant and parent village has experienced very rapid economic development so that many households have expanded their oil palm plantations. This indication is also reinforced by the higher average area and age of sawt plants than the other two villages. This comparison between villages will have implications for the magnitude of the impact of the PSR program on both the village economy and the household economy. Using the assumption that if the smallholder oil palm replanting program was carried out at the time of the research, the potential temporary income loss rates are presented in Table 12.

Table 12. Estimation results of temporary income loss rates for the PSR program in each village

\begin{tabular}{llrrr}
\hline \multirow{2}{*}{ No } & Indicators & \multicolumn{3}{c}{ Villages } \\
\cline { 3 - 4 } & & SK & DK & PW \\
\hline 1 & Household Income & & & \\
& General houseolds (IDR) & $2,939,796$ & $3,600,000$ & $2,395,100$
\end{tabular}


Palm oil households (IDR)

Palm oil households portion (\%)

Palm oil contribution (\%)

2 Replanting program potential

Palm oil households (\%)

Palm oil areas (\%)

3 Loss Income Estimate

Palm oil income (IDR)

Palm oil income loss (IDR)

4 Temporary Loss Income

Household economic (\%)

Region economic (\%)
$3,797,381$

31.37

40.52

15.69

50.00

$3,797,381$

$2,861,667$

$3,271,029$

$1,798,841$

$2,447,364$

$2,433,424$

75.36

54.99

99.43

30.54

26.45

67.06

Sources: Primary data processing, 2020

The contribution of oil palm farming to the three villages is relatively large both in terms of social (household) and economic value, especially in PW Village which reaches more than $60 \%$, and DK Village. The greater the contribution to the socio-economic life of the community and followed by a higher plant area and age, the greater the potential impact on villages and households. The biggest impact is in the form of potential loss of household income in PW Village, which is almost $100 \%$ because the oil palm plantations have entered the replanting period and have even passed the replanting period they should have. Replanting independently by households that have been carried out is still at the age of the sand fruit (early fruiting) and some of it is not yet productive (young palm trees). This means that PW Village is the village most vulnerable to the village economy and its households because it has the potential to lose temporary income. However, anticipatory measures have been taken in this village by shifting some households to obtain alternative sources of income outside of oil palm plantations. This is supported by the condition of the village which has already experienced rapid growth (the heyday of oil palm) so that the service sector develops well.

\subsection{Palm oil household readiness and empowerment program}

The age indicator in the oil palm replanting program, as stated by many parties, turns out to be responded differently by households as presented in their perception of the existing oil palm plantations. Community perceptions about the replanting time of their oil palm plantations are presented in Table 13.

Table 13. Households perceptions of their oil palm PSR program planning

\begin{tabular}{rlrrr}
\hline \multirow{2}{*}{ No } & Household perception & \multicolumn{3}{c}{ Village } \\
\cline { 3 - 5 } & & \multicolumn{1}{c}{ SK } & DK & PW \\
\hline 1 & It's too late than it should be & & & \\
& a. Household proportion (\%) & 33.33 & 10.00 & 27.78 \\
& b. Period of time (years) & 2.33 & 2.00 & 2.60 \\
2 & & & \\
It's not too late to be productive & 66.67 & 90.00 & 72.22 \\
& a. Household proportion (\%) & 3.20 & 2.83 & 2.20 \\
b. Period of time (years)
\end{tabular}

Sources: Primary data processing, 2020

The proportion of households that stated that their oil palm trees were not too late for replanting was greater than those who stated that they were too late even though they were over 20 years old. According to them, the existing oil palm plantations are still potential to be cultivated in 2 - 3 years because they are still able to provide an adequate source of income. This is supported by the tendency of their oil palm plantations which are still stable (fixed) and in circulation, and some even tend to 
experience an increase. Only a small proportion of households feel that their oil palm plantations have decreased productivity as presented in Table 14 .

Table 14. Palm oil household perspectives on the trend of production levels and FFB prices and fluctuations.

\begin{tabular}{|c|c|c|c|c|c|}
\hline \multirow{2}{*}{ No } & \multirow{2}{*}{ Price and produktivity } & \multicolumn{3}{|c|}{ Villages } & \multirow{2}{*}{ Average } \\
\hline & & SK & DK & PW & \\
\hline \multirow[t]{5}{*}{1} & Productivity trend & & & & \\
\hline & a. Increasing & 0.00 & 4.35 & 0.00 & 1.45 \\
\hline & b. Stabil & 42.86 & 39.13 & 50.00 & 44.00 \\
\hline & c. Decerasing & 7.14 & 21.74 & 5.00 & 11.29 \\
\hline & d. Fluctuation & 50.00 & 34.78 & 45.00 & 43.26 \\
\hline \multirow[t]{5}{*}{2} & Price trend & & & & \\
\hline & a. Increasing & 0.00 & 4.35 & 0.00 & 1.45 \\
\hline & b. Stabil & 0.00 & 34.78 & 30.00 & 21.59 \\
\hline & c. Decerasing & 14.29 & 17.39 & 20.00 & 17.23 \\
\hline & d. Fluctuation & 85.71 & 43.48 & 50.00 & 59.73 \\
\hline \multirow[t]{5}{*}{3} & FFB Prices (IDR) & & & & \\
\hline & a. Highest Price & $1,533.33$ & $1,410.00$ & $1,529.41$ & $1,490.92$ \\
\hline & b. Lowest prices & 833.33 & 767.14 & 691.18 & 763.88 \\
\hline & c. Averrage & $1,183.33$ & $1,088.57$ & $1,110.29$ & $1,127.40$ \\
\hline & d. Price Gap & 700.00 & 642.86 & 838.24 & 727.03 \\
\hline
\end{tabular}

Sources: Primary data processing, 2020

Production fluctuations are also followed by fluctuations in the FFB price received by farmers and even tend to decline. During the last 6 months, the prices received by farmers varied greatly with the difference between the highest and lowest prices being very contrasting. The fluctuation in the price of FFB is estimated to be due to the uncertainty of the world economy, especially due to the COVID-19 pandemic and in general, the price of FFB from old oil palm trees is much lower than that of productive age oil palm. However, the farmers already have a land-use plan for their oil palm plantations and generally hope that they can be replanted with oil palm. The magnitude of the impact of the temporary loss of income due to the smallholder oil palm replanting program both on the regional economy and the households of oil palm farmers. The productivity and price of FFB which tends to decline, the period for returning to produce economic production, and then the limited capital resources to survive during the replanting process means that oil palm farmer households need a substitute source of income. Learning from the case of the impact of thick smoke due to forest and land fires in 2015, economic recovery has turned out to be quite effective through empowerment programs and strengthening household economic capacity in the DMPA (Desa Makmur Peduli Api) program. Exposure to haze and long drought has resulted in the productivity of plants such as Duku drastically decreased from the normal 120 stems can harvest 20 tons but after the forest and land fires dropped dramatically to 4 tons (Novra et al, 2019). Forest and forest fires coincided with the emergence of the pistil of the durian fruit, causing the still to fall so that the tree did not bear fruit and if there were usually 10 pieces/trunk and according to residents, this was exactly what happened in 1997 ago. The same thing happened to plantation crops in the form of a drastic decrease in palm productivity due to smog due to disruption of the photosynthetic process and according to Erwinsyah (2014) that restoring the productivity of oil palm plants naturally takes $2-3$ years.

\section{Conclussion}

It is important to determine the impact of the SPR program in stages as a material for consideration in formulating more anticipatory and responsive policies so that they are right on target. The indicator of temporary loss of income is generated through a gradual calculation at three economic levels, namely household (micro), sectoral (agriculture), and regional (macro) economy. The calculated indicator 
value is in the form of a relative value that can be used as a reference in decision making, using the approach of the proportion of affected households and the level of temporary income loss, but in general, the two approaches have a unidirectional relationship. The method developed in stages in this paper is recommended to be used in making decisions in government intervention policies in the context of handling the negative impact of the SPR program as well as programming and community empowerment activities.

\section{References}

[1]. Rahman, R.F. 2019. The prospect of palm oil can alleviate the economic problems of smallholders? SawitMagazine.co.id. https://www.sawit.or.id/prospek-kelapa-sawit-dapatmengentas-permasalahan-ekonomi-petani-rakyat-kelapa-sawit-benar-kah/.

[2]. Nasihin I.A, 2012. All about palm oil: Analysis of palm oil production potential. Report on oil palm cultivation at Palm Oil Polytechnic Citra Widya Education. https://angganasihin.blogspot.com/2013/02/potensi-produksi-kelapa-sawit.html

[3]. Saragih, B. 2018. Indonesian palm oil industry: Social, economic and environmental issues. Indonesian palm oil magazine, palm oil product, and technology information media. https://www.sawit indonesia.com/industri-minyak-sawit-indonesia-isu-sosial-ekonomi-danlingkungan-bagian-viii/

[4]. Reily, M., 2019. Stagnating palm oil replanting program. Katadata.co.id article. https://katadata.co.id/ekarina/berita/5e9a55dd1e628/program-peremajaan-sawit-rakyat-tersendat

[5]. Larasati R.A. 2019. The future of the Indonesian palm oil industry is in the hands of millennials. Kompas.com. https:/money. kompas.com/read/2019/11/28/164046026/masa-depan-industrikelapa-sawit-ri-ada-di-tangan-milenial.

[6]. Biocond, 2016. Minimizing the impact of haze on plantation agricultural plants, a community of organic cultivation observers in agriculture, plantation, animal husbandry, and fisheries Yogyakarta. http://biocond jogja.blogspot.com/2016/

[7]. Anggreany S., S. Dwi. 2016. Farmer particiation in oil palm replanting program in Jambi Province. Penyuluhan Journal 12(1): 1-14. https://doi.org/10.25015/penyuluhan. v12i1.11315

[8]. Heryanto R., S. Murdy, Aprolita. 2018. Factors associated with farmers' decisions on oil palm rejuvenation in Sungai Bahar District, Muaro Jambi Regency. https://repository. unja.ac.id/3295/1/JURNAL_RIAN\%20HERYANTO_D1B011017.pdf

[9]. Info Sawit, 2019. Independent smallholders asking the requirements for the SPR program to be easier. Cross News: https://repository.unja.ac.id/3295/1/JURNAL RIAN\%20HERYANTO D1B011017.pdf

[10]. Indonesian Vegetable Oil Association (IVOA), 2020. The government relaxes more requirements for the rejuvenation of people's palm oil. Investor Indonesia Daily: https://gimni.org/pemerintahperlonggar-lagi-syarat-peremajaan-sawit-rakyat/,

[11]. Nazam Z. 2014. Palm oil replanting: The appropriate technology and its challenges. http://nazambun.blogspot.co.id/2014/02/html.

[12]. Novra, A., Suparjo, 2020. Collective action model: Facing temporary loss income while the rubber replanting program. IOP Conf. Series: Earth and Environmental Science 518 (2020) 012059 IOP Publishing. https://doi.org/10.24903/jam.v4i1.511

[13].FAO (Food and Agriculture Organization), 2007. The agricultural household - concepts and definitions: Handbook on Rural Households' Livelihood and Well-Being. http://www.fao.org/docrep/w9500e/w9500e12.htm

[14].WGH (The Wye Group Handbook). 2007. Livelihood and well-being statistics on rural development and agriculture household income, United Nations Economic Commission for Europe (UNECE) and Food and Agriculture Organization of the United Nations (FAO) 
Organisation for Economic Co-operation and Development (OECD) The World Bank Statistical Office of the European Communities (Eurostat). https://unece.org/fileadmin/DAM/press/pr2005/ 05stat p04e.htm

[15]. Thompson L. 2018. Sources of household income. Pocketsence Article on Managing your Money. https://pocketsense.com/sources-household-income-7313.html

[16].Kagan $J$ and T.J. Catalano. 2020. Household Income. Investopedia Family Finances. https://www.investopedia.com/terms/h/household income.asp\#: : text=Household $\% 20$ income $\% 2$ 0is $\% 20$ generally $\% 20$ defined,members $\% 20$ of $\% 20$ the $\% 20$ same $\% 20$ household.

[17].Ali, A.F.M. 2019. Difference between income and expenditure method in measuring poverty in Kelantan, Malaysia. International Journal of Economics, Management and Accounting 27 (1): 140. https://journals.iium.edu.my/enmjournal/index.php/enmj/article/view/594

[18].Eurostat. 2012. Archive: GDP and household account at the regional level: Eurostat Satisitical Explained. https://ec.europa.eu/eurostat/statistics-explained/index.php?title=Archive:GDP and household accounts at regional level\&oldid $=82544$

[19]. Kavonius I.K., V.M. Tormaletho. 2003. Household income aggregates in micro and macro statistics. Statistical Journal of the United Nations Economic Commission for Europe 20 (1): 9 25. https://content.iospress.com/articles/statistical-journal-of-the-united-nations-economiccommission-for-europe/sju00541

[20].OECD (Organization for Economic Cooperation and Development), 2001. Social and welfare statistics. Handbook of Household Surveys, Revised Edition, Studies in Methods, Series F, No. 31, United Nations, New York, 1984, para. 13.15. Last updated on October 31 th, 2001. http://socialjustice.nic.in/UserView/PrintUserView?mid=76786

[21]. Rashidin, M.S., S. Javed, B. Liu, W. Jian, 2020. Ramifications of households' Nonfarm income on agricultural productivity: Evidence from a rural area of Pakistan. SAGE Open: Original Research. January-March: 1-13. https://doi.org/10.1177\%2F2158244020902091

[22]. Chikobola, M.M and M. Sibusenga. 2016. Employment and income sources: Key determinants of off-Farm activity participation among rural households in Northern Zambia. International Journal of Agricultural Economics. 1 (3): 91-98. https://doi.org/10.1155/2019/7246176

[23].Abdallah A.H, Ayamga, M Awuni, J.A. 2019. Impact of agricultural credit on farm income under the Savanna and Transitional zones of Ghana. Agricultural Finance Review, 79(1), 60 84. https://doi.org/10.1177\%2F2158244020902091

[24].Davisa B.S. DiGiuseppeb, A. Zazzac. 2017. Are African households (not) leaving agriculture? Patterns of households' income sources in rural Sub-Saharan Africa, Food Policy 67: 153-174. https://doi.org/10.1016/j.foodpol.2016.09.018

[25].Novra, A., Suparjo, S., Latief, A., Syarif, S. 2020. Economic recovery for smallholder oil palm plantations affected by land and forest fires. Abdimas Mahakam Journal, 4(1), 1-7. https://doi.org/10.24903/jam.v4i1.511

[26]. Novra, A., Adriani, Suparjo, S. Novianti, Nelson. 2019 Strengthening the business of farmer groups engaged in waste-based oil palm-cattle integration in Mestong District. Riau Journal of Empowerment 2 (2): 43-54. https://doi.org/10.31258/raje.2.2.43-54

[27].Leatherman, J.C \& D.W. Marcouiller (1996). Income distribution characteristics of rural economic sectors: Implications for local development policy. Growth and Change: A Journal of urban and regional policy 27(4): 434-454. https://doi.org/10.31258/raje.2.2.43-54

[28].Vatta K. \& R.S. Sidhu (2010) Rural non-farm employment, income distribution, and poverty: Micro-level evidence from Punjab. Indian Journal. of Agriculture Economic. 65 (4): 693-709. DOI: 10.22004/ag.econ.204720, https://ideas.repec.org/a/ags/inijae/204720.html 
[29].Escobal, J. 2001. The determinants of non-farm income diversification in rural Peru, Nine Development Journal 29 (3): 497-508. https://www.eldis.org/document/A16476

[30].FAO (Food and Agricultural Organization) 1998. "Rural non-farm income in developing countries, Part III of the state of food and Agriculture", FAO: Rome. https://www.eldis.org/document/A16476

[31]. WHO (World Health Organization). 2015. Aging and productivity: The World report on aging. https://www.who.int/ageing/features/productivity/en/

[32]. Teame, G.T., T.Y.M. Moldu. 2016. Factors Affecting Rural Households' Income Diversification: Case of Zoba Maekel, Eritrea. American Journal of Business, Economics, and Management 4(2):

7-15. http://www.openscienceonline.com/journal/archive2?journalId=709\&paperId=3201

[33]. Supan, A.B, M Weiss, 2016. Productivity and age: Evidence from work teams at the assembly line. The Journal of the Economics of Ageing 7: $30-42$. https://doi.org/10.1016/j.jeoa.2015.12.001

[34]. Skirbekk V. 2004. Age and individual productivity: A literature survey. Vienna Yearbook of Population Research: 133-154. https://econpapers.repec.org/article/vidyearbk/v 3a2 3ay 3a2004_3ai_3a1_3ap_3a133-154.htm

[35].Han X., Y Cheng. 2020. Consumption and productivity-adjusted dependency ratio with household structure heterogeneity in China. The Journal of the Economics of Ageing 17. https://doi.org/10.1016/j.jeoa.2020.100276

[36]. Adeoti A.I. 2008. Factors influencing irrigation technology adoption and its impact on household poverty in Ghana. Journal of Agriculture and Rural Development in the Tropics and Subtropics, 109 (1), 51-63. https://www.jarts.info/index.php/jarts/article/view/73

[37]. Mponela P, G.B. Villamor, S. Snapp, L. Tamene, Q.B. Le, C. Borgemeister. 2020. The role of women empowerment and labor dependency on the adoption of integrated soil fertility management in Malawi, Soil Use and Management 2020: 1-13. https://doi.org/10.1111/sum.12627. 